\title{
How to improve the distribution maps of habitat types at national scale
}

\author{
E. Carli ${ }^{1} \cdot$ M. Massimi ${ }^{1}$ D $\cdot$ P. Angelini ${ }^{2} \cdot$ L. Casella $^{2} \cdot$ F. Attorre $^{1} \cdot$ E. Agrillo $^{3}$
}

Received: 5 April 2020 / Accepted: 30 May 2020 / Published online: 12 June 2020

(c) Accademia Nazionale dei Lincei 2020

\begin{abstract}
Annex I habitat types are a key factor for biodiversity conservation in Europe and distribution maps are essential for assessing their conservation status.

We aim to increase the responsiveness to habitat knowledge needs and to propose the use of data collected at local scale for assessing a key indicator such as the Area of Occupancy (AOO) of habitats. In this paper, starting from the 4th Report of Habitats Directive data, we present a multi-source approach that allows national habitat distribution maps to be refined and their AOO estimated, by combining certified available information on habitat maps and vegetation databases.

For the first time a comprehensive up-to-date knowledge on habitat distribution at national scale is now available; our approach will be an essential tool for the implementation of the Habitats Directive and to achieve the goals of EU biodiversity strategy in Italy.
\end{abstract}

\section{Graphic abstract}

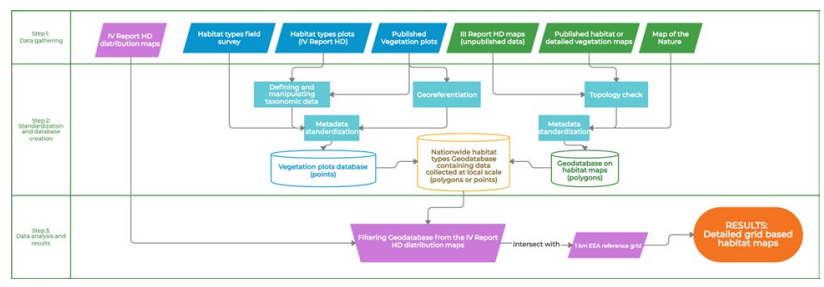

Keywords Habitats Directive $\cdot$ Forests · Grasslands $\cdot$ Habitat mapping $\cdot$ Area of occupancy $\cdot$ Vegetation databases

E. Carli and M. Massimi equal contribution.

M. Massimi

marco.massimi@hotmail.com

1 Department of Environmental Biology, Sapienza University of Rome, IT-00185 Rome, Italy

2 Department for Biodiversity Conservation, Institute for Environmental Protection and Research (ISPRA), via Vitaliano Brancati, 48, 00144 Rome, Italy

3 Operational Center for Environmental Monitoring, Institute for Environmental Protection and Research (ISPRA), via Vitaliano Brancati, 48, 00144 Rome, Italy

\section{Introduction}

Habitat types listed in Annex I of the Council Directive 92/43/EEC (Habitats Directive) are a key component of biodiversity (Legg and Nagy 2006; Bunce et al. 2013; Proença et al. 2017) and their conservation is one of the main goals stated in the Biodiversity Strategy of the European Union (Balmford 2005; Gigante et al. 2018; Jongman 2013; https ://ec.europa.eu/environment/nature/biodiversity/strategy/ index_en.htm).

Habitat occurrence is one of the indicators needed to assess the conservation status of the habitats allowing the estimation of their loss or expansion. To quantify and monitor habitats and their changes in time and space, different criteria are used in conservation assessment at global scale (Lelli et al. 2018; 
Rodwell et al. 2018). Area of Occupancy (AOO) is the reference term for habitat area assessment in the European Red List of Habitats (Janssen et al. 2016) and for the calculation of the Favourable Reference Area (FRA) value in the assessment of conservation status of Annex I habitat types (Bijlsma et al. 2018).

In the context of the Habitats Directive two requirements encompass information about habitat occurrence: distribution maps and surface area. For each habitat type, every 6 years maps of distribution at national level with a spatial resolution of $10 \mathrm{~km}$ grid (https://www.eea.europa.eu/data-and-maps/data/ eea-reference-grids-2) must be submitted and the surface area expressed in $\mathrm{km}^{2}$ must be provided for each biogeographic region. Following the guidelines for the assessment of conservation status in the Habitats Directive (Evans and Arvela 2011; DG Environment 2017), distribution maps should be based on the results of a comprehensive national mapping or inventories of the habitats but in fact maps are often derived by expert judgment.

Indeed, distribution maps are not available at an adequate spatial resolution for the national territory and thus recording changes in the area covered by each habitat type can be a challenge (Evans and Arvela 2011; Genovesi et al. 2014; Angelini et al. 2016; DG Environment 2017). Moreover, habitat types can often show successional relationships when they are contiguous in the landscape and the creation of very accurate maps is problematic due to the difficulty in determining a clear-cut boundary (EEA 2014).

This study represents a first attempt to fill this knowledge gap at national level by downscaling and refine the $10 \mathrm{~km}$ EEA reference grid, not suitable for evaluations of conservation status due to the coarse grain (Evans and Arvela 2011; DG Environment 2017), through the aggregation of available national mapping and inventories of the habitats. The result will allow to rely on more detailed spatial data to extract values of surface cover and a more detailed assessment of the habitat AOO. Herewith, we present an application to test the approach to three habitat types, with diverse pattern of distribution, through the interpolation of all available habitat maps with georeferenced vegetation databases.

The specific aims of this paper are to: (1) show the methodologies applied in the approach proposed, (2) increase the responsiveness to habitat knowledge needs and (3) propose the use of quantitative data collected (i.e., from spatial and field vegetation databases) for assessing the habitats national distribution.

\section{Materials and methods}

\subsection{Study area}

Italy covers an area of about $301,000 \mathrm{~km}^{2}$ in southern Europe, and it is one of the main peninsulas in the Mediterranean basin. It is characterized by a huge landscapes heterogeneity, result of a complex geological dynamism starting from the Upper Cretaceous. There are two main mountain ridges, the Alps in the northern and the Apennines in the southern that run along the whole peninsula. In the Italian territories are also included the main big islands of the Mediterranean Sea, besides several minor islands and archipelagos.

In our study, we selected the following grasslands and forests habitat types to test our proposal:

- $6210(*)$-Semi-natural dry grasslands and scrubland facies on calcareous substrates (Festuco-Brometalia) (*important orchid sites). It is one of the most widespread grassland habitats in Italy and is particularly relevant to understand vegetation dynamics and changes (Falcucci et al. 2007) and conservation issues at European scale (Plieninger et al. 2014; Carli et al. 2018b);

- 9250-Quercus trojana woods. Broad leaved semideciduous forests dominated by Quercus trojana. It is a rare and very localized habitat in Italy and of relict origin (Francini Corti 1966). It has been recognized only in two Administrative regions (Apulia and Basilicata) of Southern Italy;

- 9340-Quercus ilex and Quercus rotundifolia forests. Broad leaved evergreen forests dominated by Quercus ilex. It is one of the most widespread forest habitats in the Mediterranean Region.

\subsection{Data collection and preparation of the habitat maps}

To produce the habitat maps, we accessed the official Article 17 distribution maps from the 4th Report (available at: https://cdr.eionet.europa.eu/it/eu/art17/envxuwp6g/index _html?\&page $=1$ ) and we collected all available and validated habitat maps and vegetation databases, as described below.

For the habitat maps, we collected the following data (see Table 1 for further details):

- Unpublished habitat polygon maps inside the Natura 2000 Network produced by vegetation experts and collected by ISPRA (Italian Institute for Environmental Protection and Research) for the III Report of the Habi- 
Table 1 Data sources for habitat maps

\begin{tabular}{|c|c|c|c|c|c|}
\hline Italian administrative regions & Data availablity & Data source & Map scale & EPSG* $^{*}$ & Year \\
\hline Aosta Valley & Unpublished data & 3rd Italian national report & 1: 10000 & 32,632 & 2012 \\
\hline Piedmont & Not yet published & https://www.geoportale.piemonte.it/geocatalogorp/ & 1: $10000-1: 25000$ & NA & 2008 \\
\hline Lombardy & Unpublished data & 3rd Italian national report & 1: $10000-1: 25000$ & 32,632 & 2012 \\
\hline Trentino & Open data & https://webgis.provincia.tn.it/wgt/ & 1: 10000 & 32,632 & 2018 \\
\hline South Tyrol & Open data & https://geocatalogo.retecivica.bz.it/geokatalog/\#! & 1: 10000 & 25,832 & 2009 \\
\hline Veneto & Open data & $\begin{array}{l}\text { https://www.regione.veneto.it/web/agricoltura-e-fores } \\
\text { te/download }\end{array}$ & 1: $10000-1: 25000$ & 3003 & 2012 \\
\hline Friuli-Venezia Giulia & Open data & $\begin{array}{l}\text { https://irdat.regione.fvg.it/WebGIS/GISViewer. } \\
\text { jsp?template=configs:ConfigMAAS/AreeNaturaliTut } \\
\text { elate.xml }\end{array}$ & 1: 10000 & 6708 & 2012 \\
\hline Liguria & Unpublished data & 3rd Italian national report & $1: 10000$ & & 2012 \\
\hline Emilia-Romagna & Open data & $\begin{array}{l}\text { https://ambiente.regione.emilia-romagna.it/it/parch } \\
\text { i-natura2000/consultazione/cartografia-interattiva }\end{array}$ & 1: $10000-1: 25000$ & 5659 & 2014 \\
\hline Tuscany & Open data & $\begin{array}{l}\text { https://www502.regione.toscana.it/geoscopio/cartoteca. } \\
\text { html }\end{array}$ & 1: 10000 & 3003 & 2017 \\
\hline Marche & Open data & $\begin{array}{l}\text { https://www.ambiente.marche.it/Ambiente/Natura/ } \\
\text { ReteNatura2000/Cartografia.aspx }\end{array}$ & 1: 10000 & 32,632 & 2014 \\
\hline Umbria & Open data & $\begin{array}{l}\text { https://www.isprambiente.gov.it/it/servizi-per-lambi } \\
\text { ente/sistema-carta-della-natura }\end{array}$ & 1: 50000 & 32,632 & 2013 \\
\hline Lazio & Unpublished data & 3rd Italian national report & 1: $10000-1: 25000$ & 32,632 & 2012 \\
\hline Abruzzo & Unpublished data & 4th Italian national report & $1: 10000-1: 25000$ & 32,632 & 2018 \\
\hline Molise & Unpublished data & 3rd Italian national report & 1: $10000-1: 25000$ & 3003 & 2012 \\
\hline Campania & Open data & $\begin{array}{l}\text { https://www.isprambiente.gov.it/it/servizi-per-lambi } \\
\text { ente/sistema-carta-della-natura }\end{array}$ & 1: 25000 & 32,632 & 2018 \\
\hline Apulia & Open data & $\begin{array}{l}\text { https://www.paesaggiopuglia.it/notizie/345-rete-natur } \\
\text { a-2000-individuazione-di-habitat-e-specie-vegetali-e- } \\
\text { animali-di-interesse-comunitario-nella-regione-pugli } \\
\text { a.html }\end{array}$ & 1: $10000-1: 25000$ & 32,633 & 2018 \\
\hline Basilicata & Open data & https://rsdi.regione.basilicata.it/Catalogo/ & 1: $10000-1: 25000$ & 32,633 & 2012 \\
\hline Calabria & Unpublished data & 3rd Italian national report & 1: 10000 & 32,633 & 2012 \\
\hline Sicily & Unpublished data & 3rd Italian national report & 1: $10000-1: 25000$ & 32,633 & 2012 \\
\hline Sardinia & Unpublished data & 3rd Italian national report & 1: $10000-1: 25000$ & 32,632 & 2012 \\
\hline
\end{tabular}

${ }^{*}$ Geodetic parameter dataset (www.epsg.org)

tats Directive (Art. 17, 92/43/CEE) (available at: https ://cdr.eionet.europa.eu/it/eu/art17/envupyjhw/);

- Published habitat polygon maps produced by vegetation experts and freely available in Institutional web sites (data refer to Natura 2000 Network for all Administrative regions but Piedmont and Apulia);

- For the two Administrative regions which lack habitat maps (Umbria and Campania), we used the Map of Nature (https://www.isprambiente.gov.it/it/servizi-perlambiente/sistema-carta-della-natura/carta-della-natur a-alla-scala-1-50.000), only for the habitat 9340, for which the crosswalk between the CORINE Biotopes category and the Annex 1 habitat code is one to one, that is $9340=45.3$.
For the vegetation plots, data came from three different sources:

- Plots carried out during this project and attributed to habitat types;

- unpublished plots collected from regional referents of the IV Report of the Habitats Directive (Art. 17, 92/43/CEE) and assigned to habitat types;

- Plots published in scientific journals and stored in "Vegetation-Plot Database of the Sapienza University of Rome" (Agrillo et al. 2017).

Following the guidelines indicated by ISPRA in the technical report concerning the monitoring of Habitats Directive (Angelini et al. 2016), plant names were standardized following the checklist of (Conti et al. 2005, 2007). All 
vegetation data were stored in a single database using the software Turboveg 2.141 (Hennekens and Schaminée 2001). The abundance values of the literature data were stored according to Braun-Blanquet cover scale, and being transformed to percentage values for the analyses. Bibliographic data were assigned to a specific habitat using a script created in Turboveg according to an expert-system assignment procedure, based on the relevant scientific literature (Biondi et al. 2009; Angelini et al. 2016, 2018; Janssen et al. 2016). See Table 2 for the expert system scripts. Once vegetation plots were assigned to each habitat type, we exported three layers of points.

A long process of taxonomy and metadata standardization, georeferencing and cleansing of topological problems was required to produce a comprehensive georeferenced geodatabase using QGIS Wien 3.4.12 (QGIS Development Team 2018).
Data were aggregated on the finer $1 \mathrm{~km}$ EEA reference grid. This spatial resolution is considered useful for assessing the conservation status of habitats at national scale and suitable as an intermediate spatial scale to proceed from georeferenced maps and datasets to the European reports (Tsiripidis et al. 2018) and it has already been used for similar purposes (Marignani et al. 2017; Carli et al. 2018a).

The $1 \mathrm{~km}$ EEA reference grid distribution maps of the three habitats were produced according to the following steps:

1. Starting from the polygon habitat maps, using the select by location tool in QGIS, we identified the $1 \mathrm{~km}$ cells that intersect, are included, include or touch the boundaries of the polygons of the habitats map;

2. We also selected grid cells intersecting the point habitat maps obtained from the vegetation database;

Table 2 Expert-based selection for each habitat type mapped from Vegetation-Plot Database of the Sapienza University of Rome (Agrillo et al. 2017)

\begin{tabular}{ll}
\hline Habitat & Script \\
\hline 6210 & (Bromus erectus $>13$ OR Bromus erectus s. erectus $>13$ ) (MD) OR Avenula praetutiana OR Brachypodium rupestre OR Eryngium \\
amethystinum OR Festuca circummediterranea OR Galium lucidum OR Koeleria lobata OR Phleum hirsutum s. ambiguum OR \\
Sanguisorba minor OR Sanguisorba minor s. minor AND NOT (Stipa eriocaulis s. eriocaulis $>38$ OR Stipa austroitalica s. austroi- \\
talica $>38$ OR Spartium junceum $>13$ OR Rosmarinus officinalis $>13$ OR Rosa canina $>38$ OR Quercus robur s. robur $>13$ OR \\
Quercus pubescens s. pubescens $>13$ OR Quercus ilex s. ilex $>13$ OR Quercus cerris $>13$ OR Prunus spinosa s. spinosa $>13$ OR \\
Pinus sylvestris $>13$ OR Pinus halepensis $>13$ OR Juniperus oxycedrus s. oxycedrus $>13$ OR Juniperus oxycedrus $>13$ OR Juni- \\
perus communis $>13$ OR Fraxinus ornus s. ornus $>13$ OR Erica arborea $>13$ OR Cytisus scoparius s. scoparius $>13$ OR Corylus \\
avellana $>13$ OR Cistus creticus s. eriocephalus $>13$ OR Buxus sempervirens $>13)$ \\
Quercus trojana s. trojana $>38$ AND NOT (Quercus ilex s. ilex $>68$ OR Quercus pubescens s. pubescens $>68$ OR Quercus cerris OR \\
Quercus frainetto $>68)$ \\
Quercus ilex $s$. ilex $>15$ AND NOT (Fagus sylvatica s. sylvatica $>15$ OR Pinus halepensis $>15$ OR Pinus pinaster $>15$ OR Pinus \\
pinea $>15$ OR Quercus cerris $>15$ OR Quercus frainetto $>15$ OR Quercus petraea s. petraea $>15$ OR Quercus robur $>15$ OR \\
Quercus suber $>15)$
\end{tabular}

(Cover values expressed in percentual, $M D$ mandatory species)

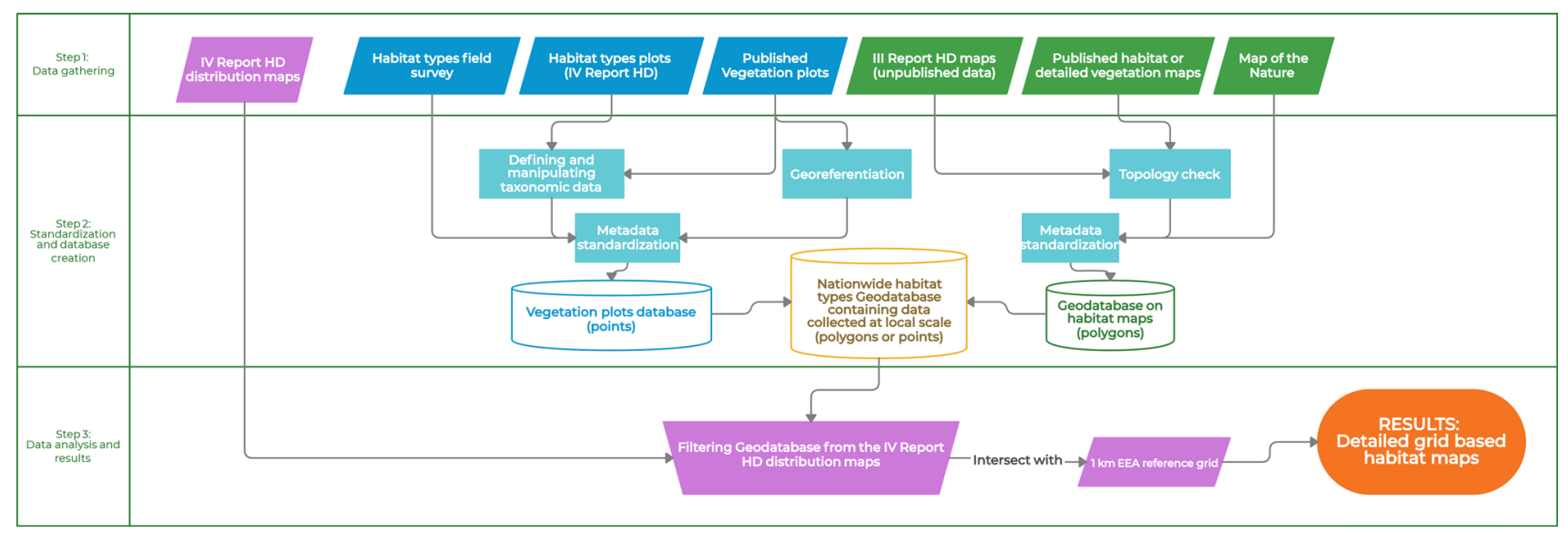

Fig. 1 Graphical synthesis of the approach that we propose for the realisation of the habitat distribution maps $1 \mathrm{~km}$ grid based 
3. We filtered the selected $1 \mathrm{~km}$ grid cells falling in the IV Report HD distribution maps.

Figure 1 graphically synthetises the process that we used for the creation of the maps.

\section{Results}

Using a multi-source approach $1 \mathrm{~km}$ EEA reference grid distribution maps for three target habitats of Community Interest were produced, as shown in Figs. 2, 3, 4.

In Table 3, referring to the three habitat types here discussed, results from calculation of the estimated AOO on the whole national territory (inside and outside the Natura2000 Network), based on the $1 \mathrm{~km}$ EEA reference grid are compared with the latest Art 17 National Report data, i.e., the available AOO derived from the $10 \mathrm{~km}$ EEA reference grid quadrats and the range of values reported for cover areas in $\mathrm{km}^{2}$ based mainly on expert opinion and related mainly to Natura2000 Network. This schematic comparison suggests the amelioration in data estimate provided by the approach here proposed.

\section{Discussion}

In this paper, we propose a multi-source approach to define habitat AOO in Italy using a $1 \mathrm{~km}$ EEA reference grid to aggregate data from habitat maps and vegetation databases starting from the distribution maps in the last HD Report.

According to Tsiripidis et al. (2018), the use of an intermediate scale seems to be adapted to the national scale. As we know the $1 \mathrm{~km}$ EEA grid has already been used for biodiversity status and vulnerability assessment along the coasts of the Mediterranean Sea (Marignani et al. 2017; Carli et al. 2018a).

Our results suggest that this approach produces a more sound estimate of the habitat area with surface values much closer to the expert based estimated in the 4th report, derived from Natura 2000 Network databases. It also avoids the huge overestimation resulting in the number of quadrats of the $10 \mathrm{~km}$ EEA reference grid (Table 3 ) providing the possibility of reaching a narrower range of values to indicate the actual area occupied.

This approach seems to be most suitable to estimate the AOO of habitats characterized by a national distribution like that of Habitats $6210\left(^{*}\right)$ and 9340 . At a national scale the use of $1 \mathrm{~km}$ grid produced a more accurate assessment in
Fig. 2 Distribution map of the habitat 6210(*)-Semi-natural dry grasslands and scrubland facies on calcareous substrates (Festuco-Brometalia) (*important orchid sites)

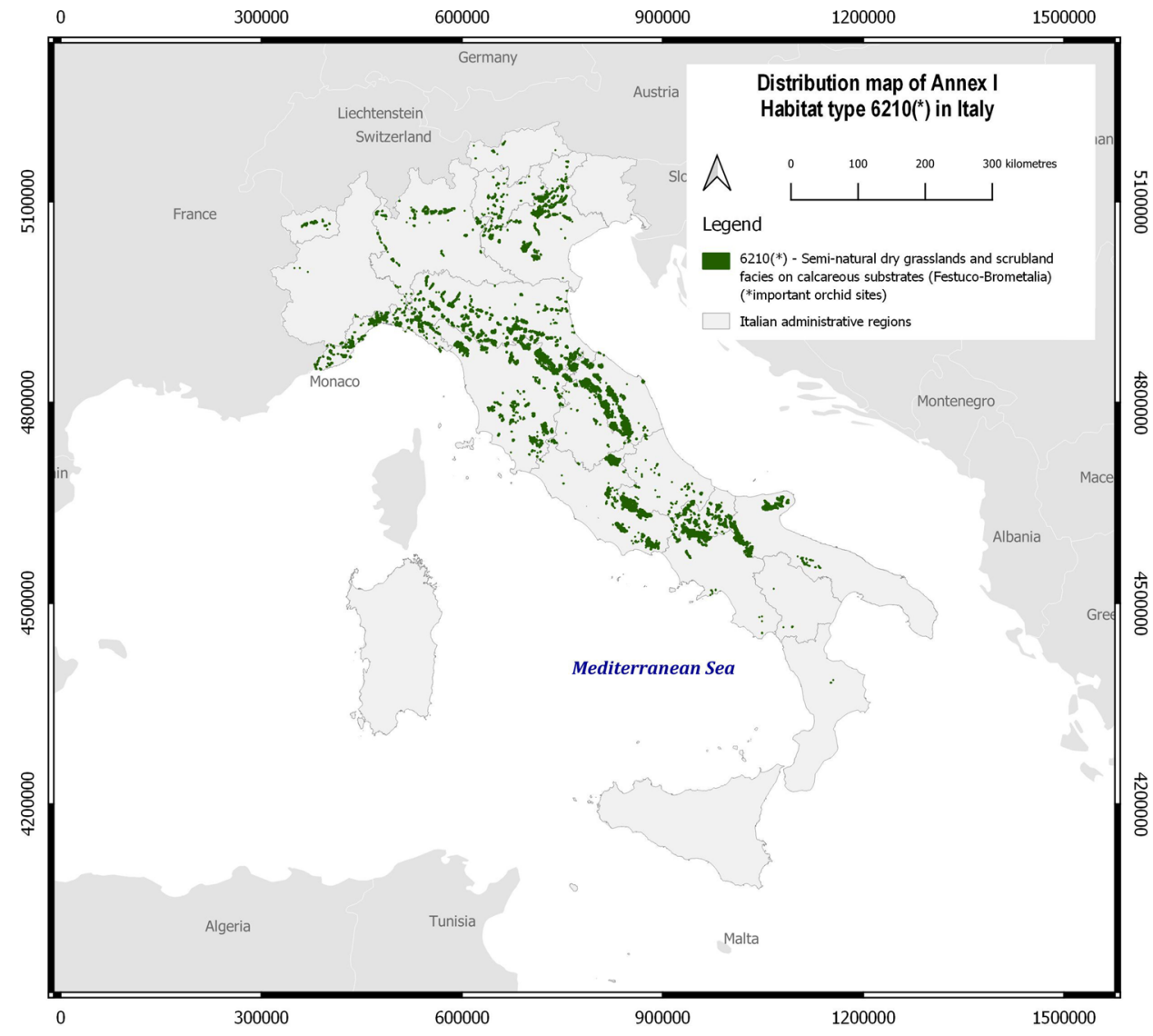


Fig. 3 Distribution map of the habitat 9250-Quercus trojana woods

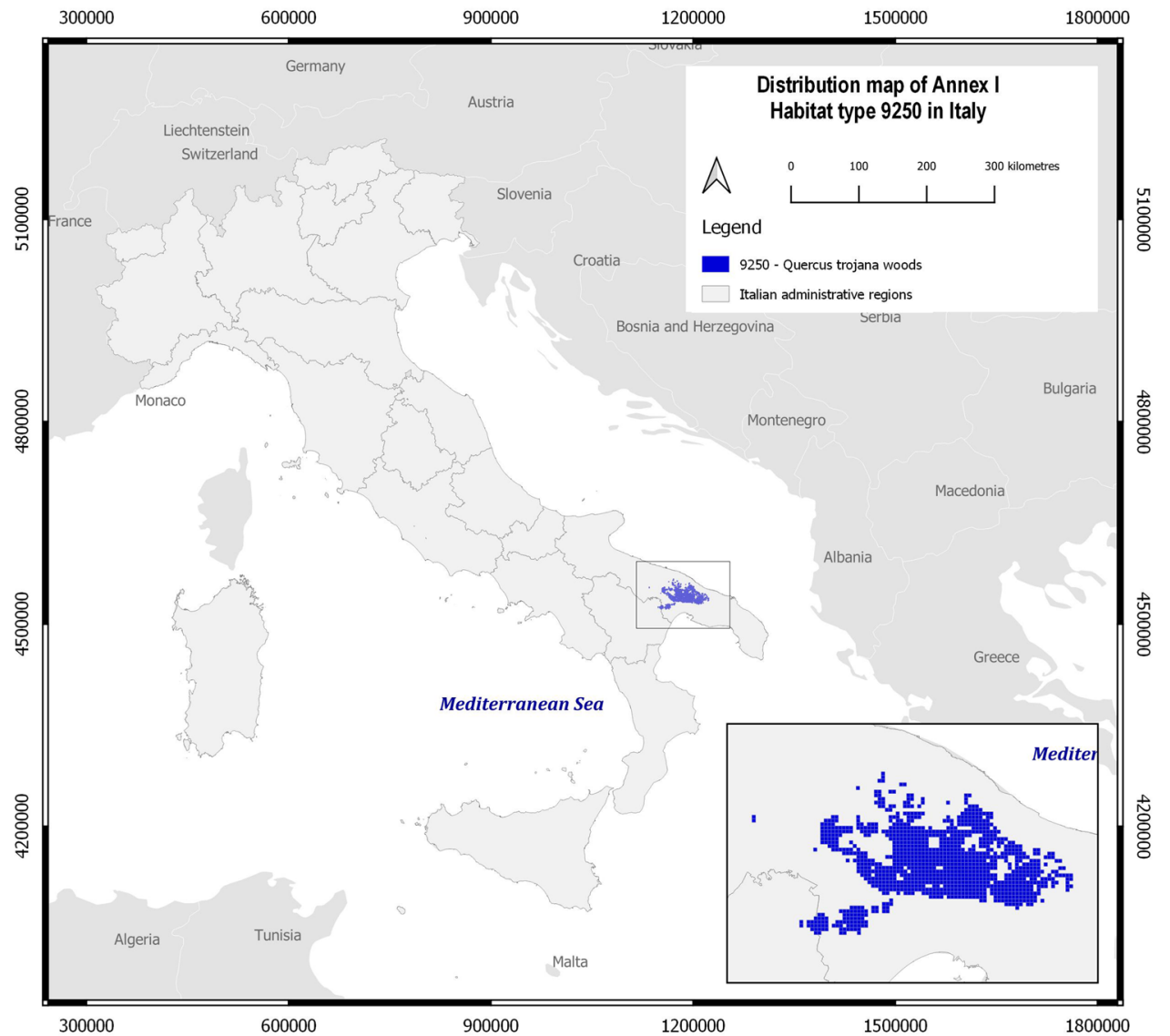

term of both of distribution and AOO compared to the $10 \mathrm{~km}$ grid (Table 3).

Conversely, for habitats such as the 9250 , which are characterized by a very localized distribution, the currently available knowledge can be considered complete, so it seems unnecessary to recalculate the area, and AOO can be calculated directly from habitat maps and vegetation databases.

Considering the importance of the conservation status assessment of habitats for the EU biodiversity policies, our results also suggest the necessity to share data in a national data repository that is freely available such as the Italian National Biodiversity Network (https://geoviewer.nnb.ispra mbiente.it/). On the other hand, practical national guidelines are necessary to provide procedures for standardizing and harmonizing multi-source data including taxonomic nomenclature, coordinate reference systems and metadata information (Agrillo et al. 2018).

Thanks to the approach here proposed, for the first time a comprehensive up-to-date knowledge on the distribution of habitats at national scale is now possible. Furthermore, we think that our approach in future could be an essential tool for developing more efficient monitoring schemes (Chiarucci 2007) and evaluating the implementation of Habitats Directive in Italy, especially for reference value indices and conservation status assessment (Bijlsma et al. 2018). In the framework of a National Plan for Habitats Directive habitats monitoring, the results will allow, together with the future integration of Earth Observation data, a more reliable set of information for habitat monitoring and assessment. 
Fig. 4 Distribution map of the habitat 9340-Quercus ilex and Quercus rotundifolia forests

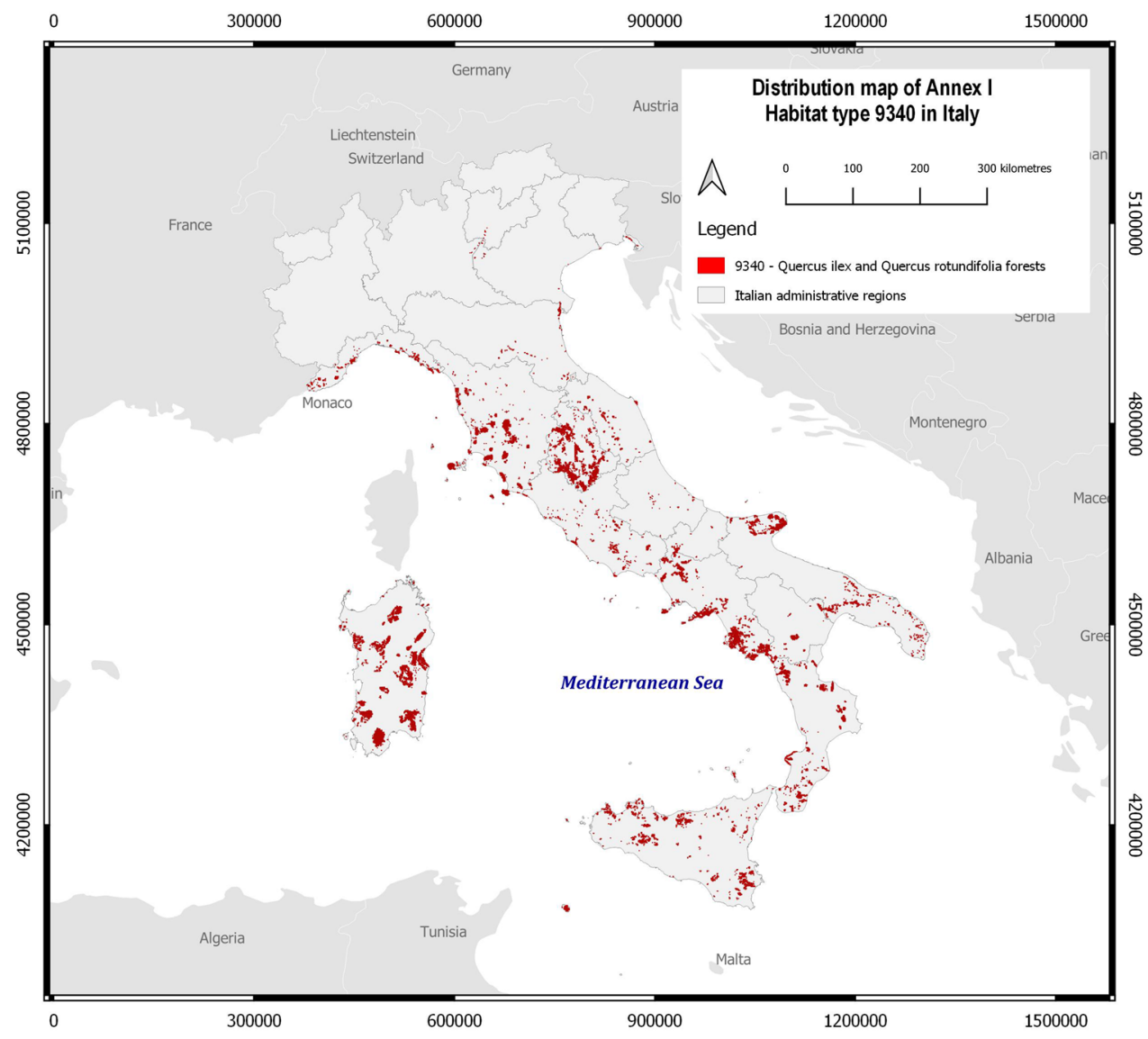

Table 3 Comparison between our estimated AOO and data from the 4th Report in each habitat type factsheet and in the relative distribution maps (data source: https://cdr.eionet.europa.eu/it/eu/art17/envxuwp6g/index_html?\&page=1)

\begin{tabular}{llll}
\hline Habitat & $6210(*)$ & 9250 & 9340 \\
\hline Estimated AOO $\left(\mathrm{km}^{2}\right) 1 \mathrm{~km}$ EEA reference grid & 9280 & 1075 & 12,339 \\
Areas $\left(\mathrm{km}^{2}\right)$ reported in 4th Report Art. 17 & $2779-6407$ & $80-455$ & $2541-7153$ \\
$\begin{array}{l}\text { Area cover calculated from the number of 10 km EEA quadrats of } \\
\text { occurrence }\end{array}$ & 147,700 & 3400 & 132,000 \\
\hline
\end{tabular}

Acknowledgements This work was developed and realized within the project "Creation of a National database of the Habitat of Community Interest for the improvement of the Environmental Statistics for cohesion policies 2014-2020 CUP: I52E18000040002", within the "NOP Governance and Institutional Capacity 2014-2020" CCI: 2014IT05M2OP002.

Funding "CUP: I52E18000040002", within the "NOP Governance and Institutional Capacity 2014-2020” CCI: 2014IT05M2OP002.

Data availability The datasets generated during and/or analysed during the current study are available from the corresponding author on reasonable request.

\section{Compliance with ethical standards}

Conflicts of interest The authors declare that they have no conflict of interest.

\section{References}

Balmford A (2005) ECOLOGY: The Convention on Biological Diversity's 2010 Target. Science (80- ) 307:212-213. https://doi. org/10.1126/science.1106281

Agrillo E, Alessi N, Massimi M et al (2017) Nationwide vegetation plot database: Sapienza university of Rome: state of the art, basic figures and future perspectives. Phytocoenologia 47:221-229. https ://doi.org/10.1127/phyto/2017/0139

Agrillo E, Alessi N, Jiménez-Alfaro B, Casella L, Angelini P, Argagnon O, Crespo G, Fernández-González F, Monteiro-Henriques T, 
Neto CS, Attorre F (2018) The use of large databases to characterize habitat types: the case of Quercus suber woodlands in Europe. Rend Fis Acc Lincei. https://doi.org/10.1007/s 12210-018-0703-x

Angelini P, Casella L, Grignetti A, Genovesi P (eds) (2016). Manuali per il monitoraggio di specie e habitat di interesse comunitario (Direttiva 92/43/CEE) in Italia: habitat. ISPRA Serie Manuali e Linee Guid 142/2016., Roma

Angelini P, Chiarucci A, Nascimbene J et al (2018) Plant assemblages and conservation status of habitats of community interest (Directive 92/43/EEC): definitions and concepts. Ecol Quest 29:87-97. https://doi.org/10.12775/EQ.2018.025

Bijlsma R-J, Agrillo E, Attorre F et al. (2018) Defining and applying the concept of favourable reference values for species and habitats under the eu birds and habitats directives. In: Examples of setting favourable reference values. Wageningen Environmental Research, Report 2929, Wageningen, p 220

Biondi E, Blasi C, Burrascano S, et al. (2009) Manuale Italiano di interpretazione degli habitat della Direttiva 92/43/CEE (Italian interpretation manual of the 92/43/EEC habitats directive). https ://vnr.unipg.it/habitat/. Accessed 1 Dec 2016

Bunce RGH, Bogers MMB, Evans D, Jongman RHG (2013) Field identification of habitats directive Annex I habitats as a major European biodiversity indicator. Ecol Indic 33:105-110. https ://doi.org/10.1016/j.ecolind.2012.10.004

Carli E, Frondoni R, Pinna MS et al (2018a) Spatially assessing plant diversity for conservation: a Mediterranean case study. J Nat Conserv 41:35-43. https://doi.org/10.1016/j.jnc.2017.11.003

Carli E, Giarrizzo E, Burrascano S, Alós Ortí MM, Del Vico E, Di Marzio P, Facioni L, Giancola C, Mollo B, Paura B, Salerno G, Zavattero L, Blasi C (2018b) Using vegetation dynamics to face the challenge of the conservation status assessment in semi-natural habitats. Rend Fis Acc Lincei. https://doi.org/10.1007/s1221 0-018-0707-6

Chiarucci A (2007) To sample or not to sample? That is the question for the vegetation scientist. Folia Geobot 42:209-216. https://doi. org/10.1007/BF02893887

Conti F, Abbate G, Alessandrini A, Blasi C (2005) An annotated checklist of the Italian vascular flora. Ministero, Palombi Editori, Roma

Conti F, Alessandrini A, Bacchetta G et al (2007) Integrazioni alla checklist della flora vascolare italiana. Nat Vicentina 10:5-74

EEA (2014) Terrestrial habitat mapping in Europe: an overview. Joint MNHNEEA Report. Technical Report 1/2014. European Environment Agency (EEA), Copenhagen, p 154

DG Environment (2017) Reporting under article 17 of the habitats directive: explanatory notes and guidelines for the period 20132018. Final version - May 2017. Brussels, pp 1-188

Evans D, Arvela M (eds) (2011) Assessment and reporting under Article 17 of the Habitats Directive-Explanatory Notes \& Guidelines for the period 2007-2012. Final version, July 2011. European Topic Centre on Biological Diversity, Paris

Falcucci A, Maiorano L, Boitani L (2007) Changes in land-use/landcover patterns in Italy and their implications for biodiversity conservation. Landsc Ecol 22:617-631. https://doi.org/10.1007/s1098 0-006-9056-4

Francini Corti E (1966) Aspetti della vegetazione pugliese e contingente paleogeico meridionale nella Puglia. Ann Accad Ital Sci For 15:137-193
Genovesi P, Angelini P, Bianchi E, et al. (eds) (2014) Specie e habitat di interesse comunitario in Italia: distribuzione, stato di conservazione e trend. ISPRA, Serie Rapporti, 194/2014

Gigante D, Acosta ATR, Agrillo E, Armiraglio S, Assini S, Attorre F, Bagella S, Buffa G, Casella L, Giancola C, Giusso del Galdo GP, Marcenò C, Pezzi G, Prisco I, Venanzoni R, Viciani D (2018) Habitat conservation in Italy: the state of the art in the light of the first European red list of terrestrial and freshwater habitats. Rend Fis Acc Lincei. https://doi.org/10.1007/s12210-018-0688-5

Hennekens SM, Schaminée JHJ (2001) TURBOVEG, a comprehensive data base management system for vegetation data. J Veg Sci 12:589-591. https://doi.org/10.2307/3237010

Janssen JAM, Rodwell JS, García Criado M et al. (2016) European red list of habitats. Part 2. Terrestrial and freshwater habitats European red list of habitats environment. Publications Office of the European Union, Luxembourg

Jongman RHG (2013) Biodiversity observation from local to global. Ecol Indic 33:1-4. https://doi.org/10.1016/j.ecolind.2013.03.012

Legg CJ, Nagy L (2006) Why most conservation monitoring is, but need not be, a waste of time. J Environ Manag 78:194-199. https ://doi.org/10.1016/j.jenvman.2005.04.016

Lelli C, Nascimbene J, Chiarucci A (2018) Are available vegetation data suitable for assessing plant diversity?. A study case in the Foreste Casentinesi National Park (Italy), Rend Fis Acc Lincei. https://doi.org/10.1007/s12210-018-0681-z

Marignani M, Bruschi D, Astiaso Garcia D et al (2017) Identification and prioritization of areas with high environmental risk in Mediterranean coastal areas: a flexible approach. Sci Total Environ 590-591:566-578. https://doi.org/10.1016/j.scitotenv.2017.02.221

Plieninger T, Hui C, Gaertner M, Huntsinger L (2014) The impact of land abandonment on species richness and abundance in the Mediterranean basin: a meta-analysis. PLoS ONE 9:e98355. https ://doi.org/10.1371/journal.pone.0098355

Proença V, Martin LJ, Pereira HM et al (2017) Global biodiversity monitoring: from data sources to essential biodiversity variables. Biol Conserv 213:256-263. https://doi.org/10.1016/j.bioco n.2016.07.014

QGIS Development Team (2018) QGIS geographic information system. Open source geospatial foundation project

Rodwell JS, Evans D, Schaminée JHJ (2018) Phytosociological relationships in European Union policy related habitat classifications. Rend Fis Acc Lincei. https://doi.org/10.1007/s12210-018-0690-y

Tsiripidis I, Xystrakis F, Kallimanis A et al (2018) A bottom-up approach for the conservation status assessment of structure and functions of habitat types. Rend Fis Acc Lincei 29:267-282. https ://doi.org/10.1007/s12210-018-0691-x

Publisher's Note Springer Nature remains neutral with regard to jurisdictional claims in published maps and institutional affiliations. 